| Research Article / Araştırma Makalesi |

\title{
Educational Digital Game Design Process for Different Player Types
}

\section{Farklı Oyuncu Tiplerine Göre Eğitsel Dijital Oyun Tasarım Süreci ${ }^{1}$}

\author{
Semra Fiş Erümit ${ }^{2}$, Furkan Kalyoncu ${ }^{3}$, Abdullah Kuzu $^{4}$, Hasan Karal ${ }^{5}$
}

\author{
Keywords \\ 1. Educational Digital \\ Game Design \\ 2. Information \\ Technologies and \\ Software Course \\ 3. Hardware Units \\ 4. Scenario Creation \\ 5. Player Types \\ 6. Developmental \\ Research Method
}

\section{Anahtar Kelimeler}

1. Eğitsel Dijital Oyun Tasarımı

2. Bilişim Teknolojileri ve Yazılım Dersi

3. Donanım Birimleri

4. Senaryo Oluşturma

5. Oyuncu Tipleri

6. Gelişimsel Araştırma Yöntemi

Received/Başvuru Tarihi

10.02.2021

Accepted / Kabul Tarihi

31.05.2021

\begin{abstract}
Purpose: This study aims to design and develop an educational digital game that explains the tasks and data transmission of hardware units in the 5th and 6th grade information technologies and software course, suitable for different player types.

Design/Methodology/Approach: The study was conducted with a developmental research method which is one of the designbased research methods. In the game design process, product design, development, and evaluation phases were carried out in accordance with the principles in developmental research method. Product design and development studies were carried out in three stages in accordance with design-based research. The studies conducted at each stage were evaluated by a team of 14 experts. Before moving to the next stage, in each step the necessary corrections were made in the game.
\end{abstract}

Findings: The first stage of the study deal with game design in which the data on writing scenario, adaptation of this scenario to different player types, and lastly some drawings on the scenario were obtained. The data was analysed, and necessary arrangements were made before moving to the next stage. In the second stage, evaluations were made for the 3D design studies of the game. At this stage, data were elicited on how different player types collect points, on the duration, on the tasks of the accessories used by different player types, on the way the player reaches to the units in the game and on the design of the characters. After obtaining these data, arrangements were made, we moved to the third stage. In the third stage, depending on the feedback obtained from the players, the interaction of the characters and the dialogue windows that appear on the screen necessary arrangements were made.

Highlights: In this study, the stages in the educational digital game design process were determined, and at the end of the study, a 3D educational game that can be played by different player types was developed in accordance with the learning outcomes in the curriculum.

Öz

Çalışmanın amacı: Bu çalışmanın amacı, 5. ve 6. sınıf bilişim teknolojileri ve yazılım dersindeki donanım birimlerinin görevlerini ve veri iletimini anlatan eğitsel dijital bir oyunun, farklı oyuncu tiplerine uygun tasarlanması ve geliştirilmesidir.

Materyal ve Yöntem: Çalışma tasarım tabanlı araştırma yöntemlerinden gelişimsel araştırma yöntemi ile yürütülmüştür. Oyun tasarım sürecinde gelişimsel araştırma yöntemine uygun olarak ürün tasarımı, geliştirme ve değerlendirme aşamaları gerçekleştirilmiştir. Ürün tasarımı ve geliştirme çalışmaları tasarım tabanlı araştırmaya uygun olarak üç aşamada gerçekleştirilmiştir. Her aşamada yapılan çalışmalar 14 kişilik uzman ekip tarafından değerlendirilmiş, oyunda gerekli düzeltmeler yapılarak bir sonraki aşamaya geçilmiştir.

Bulgular: Çalışmanın ilk aşamasında oyun kurgusuna yönelik değerlendirmeler yapılmıştır. Bu aşamada senaryo yazımı, senaryonun oyuncu tiplerine göre hazırlanması ve senaryo çizimleri ile ilgili veriler elde edilmiştir. Gerekli düzenlemeler yapıldıktan sonra ikinci aşamaya geçilmiştir. İkinci aşamada oyunun üç boyutlu tasarım çalışmalarına yönelik değerlendirmeler yapılmıştır. Bu aşamada farklı oyuncu tiplerinin puan toplama şekli, süre, farklı oyuncu tiplerinin kullandığı aksesuarların görevleri, oyuncunun oyundaki birimlere ulaşma şekilleri ve karakterlerin tasarımı ile ilgili veriler elde edilmiştir. Uzman değerlendirmesinden sonra düzenlemeler yapılarak üçüncü aşamaya geçilmiştir. Üçüncü aşamada oyundaki geri bildirim, karakterlerin birbiriyle etkileşimi ve ekrana gelen diyalog pencereleri ile ilgili veriler elde edilerek, düzenlemeler yapılmıştır.

Önemli Vurgular: Bu çalışmada eğitsel dijital oyun tasarım sürecindeki aşamalar belirlenmiş, çalışma sonunda müfredattaki kazanımlara ve farklı oyuncu tiplerine uygun üç boyutlu eğitsel bir oyun geliştirilmiştir.

\footnotetext{
${ }^{1}$ This study was developed within the scope of the TÜBITAK $1001118 \mathrm{R} 034$ project and part of the study was presented as an oral presentation at the "2nd International Conference on Science, Mathematics, Entrepreneurship and Technology Education" and included in the abstract book.

${ }^{2}$ Corresponded Author, Karadeniz Technical University, Distance Education Application and Research Center, Trabzon, TURKEY; https://orcid.org/0000-00027161-8903

${ }^{3}$ Trabzon University, Fatih Education Faculty, Department of Computer and Instructional Technology Education, Trabzon, TURKEY; https://orcid.org/0000-00032214-3347

${ }^{4}$ Antalya AKEV University, The Faculty of Economics and Administrative Sciences, Antalya, TURKEY; https://orcid.org/0000-0002-1030-0424

${ }^{5}$ Trabzon University, Fatih Education Faculty, Department of Computer and Instructional Technology Education, Trabzon, TURKEY; https://orcid.org/0000-00023555-050X
} 


\section{INTRODUCTION}

Digital games are an instructive educational tool due to the benefits they provide in educational environments. Due to the fact that digital games contain audio-visual and fun elements, they increase students' engagement and motivation, and make the classroom environment more interesting and instructive (Connolly et al., 2012; Hainey et al., 2016). For this reason, it is stated that educational games, when designed effectively, help achieve the expected educational goals. Designing digital games for educational purposes, both pedagogically and technically, is a very difficult process, and requires interdisciplinary work (Dimitriadou et al., 2020). In order for educational digital games to reach the targeted instructional goals, the scenario should be well fictionalized; the flow and fun that should be in the games should not be ignored, and all these processes should be well organized technically (Kiili, 2005; Prensky, 2004; Zeng et al., 2020).

In educational digital game designs, to what extent meaningful learning occurs with the products that are the result of the design is still a topic for debate. Although there are many design models for educational games, these models are mostly related to learning theories and game elements used in game design (Qian \& Clark, 2016). Considering the point reached by today's technologies, it is seen that the technologies used in game design, game design engines and design processes using these technologies are very important. What can be done to realize learning in game designs and how technology can be used in game design processes is an open subject for improvement (Young et al., 2012). Many educational games are simple designs that focus narrowly on academic content, use low-level visuals, and provide examples of exercises and applications like worksheets (Squire, 2003; Young et al., 2012; Vasalou et al., 2017; Lämsä et al., 2018). These game designs do not only fail to attract the attention of students, but also fall short in providing learning and motivation (Lester et al., 2014; Ninaus et al., 2020). Designing games for educational purposes requires a comprehensive interdisciplinary study, as it requires an in-depth understanding of game theories as well as sufficient knowledge on the academic subject and having high competencies at a technical level (Qian \& Clark, 2016). In addition, the graphics quality demanded by the players who experience today's technologies in many areas and the sense of reality given by the games are constantly increasing. Meeting these demanded needs means preparing quality visuals, believable animations, and designs for actors (Vasudevamurt \& Uskov, 2015). For this reason, the success of today's educational games depends on well-fictionalized scenarios and game design processes which serve in the best way for all players.

\section{Educational Digital Game Design Process and Difficulties Encountered}

Different design processes and models are used for the designing of educational digital games. Bilgili (2020) stated that educational computer game designs are carried out in three phases. The first step is the preparation phase. At this phase, the target audience of the game, the type of game (adventure, strategy, etc.) and the platform on which the game will be developed are determined. In the second phase, scenario designs are made and the elements to be used in the game and 3D models are prepared. In the third phase, the first prototype is developed by combining all game components. Aslan and Balcı (2015) have also developed a cyclic design model for educational digital games in their study. This cycle includes designing the game with game software, applying, and publishing the game, game-based learning, and feedback stages. In this model, the game software and the requirements at the design phase and the features that should be included in the game structure are mentioned. In another educational game design study, Shi and Shih (2015) mentioned the process steps to be carried out in the game design process and the game elements to be used. In this model, the focus is on game elements such as game objectives, game mechanics, interaction, narrations, competition, mystery, socialization, and flow. When many educational game design models in the literature are examined, it is seen that the design process is generally focused, narrations, game elements, game mechanics and learning principles, but the technical processes carried out while performing them are not mentioned in detail.

Designing educational digital games is a difficult and labor-intensive process. Game designers can create interesting games and designs. Educators generally focus on educational goals and effective teaching materials, but they have problems in determining how to design games that can attract students' interest (Shi \& Shih, 2015; Squire, 2003). For this reason, it is possible for educational digital games to be in accordance with pedagogical and instructional objectives and to make a technically welldesigned design with an interdisciplinary teamwork (Van Eck, 2015). In the literature, in educational game design processes; it has been stated that the story flow is not immersive; the balance of skill and struggle required for the game is not provided; the playergame interaction is not in balance and the appropriate scenario is not selected (Akgün et al., 2011; Kiili, 2005; Song \& Zhang, 2008). In the literature it has been stated that there are problems such as lack of engaging story flow in educational game design processes, lack of skill and combat balance required for playing the game, unbalanced player-game interaction and wrong choice of scenario (Aleem et al., 2016).

Story editing and scenario designs have been considered to be problematic in the educational digital game design process. The success of educational digital games depends largely on the scenario to be prepared for the targeted achievements (Jemmali et al., 2019; Zarraonandia et al., 2015). The game scenario is the game component that gives information about what the game is about, the elements in the game, the goals of the game, and the rules required to achieve these goals (Prensky, 2001). It is necessary to pay attention to the fact that the educational game scenarios are related to real life (Desurvire et al., 2004), reflect the sense of the game to the player (Prensky, 2001), attract the attention of the player and the game has an appropriate flow for the player (Kiili, 2005), and offers clear and understandable tasks in the game (Sweetser \& Wyeth, 2005). In addition, it is stated that scenarios suitable for educational purposes and target audience are not written in educational digital game designs (Dimaraki et al., 2013), teaching purposes come to the fore, game elements and fun are lacking (Archambault et al., 2008; Taşdemir \& Şüyun,

|Kastamonu Education Journal, 2022, Vol. 30, No. 1| 
2016), poor game designs are stated to negatively affect their output (Hong et al., 2009; Sung \& Hwang, 2018). Mistakes made in both the scenario and the design processes cause the game elements and fun components to remain in the background and the student's motivation in the game decreases, causing disconnections from the game (Kiili, 2005; Kocadere et al., 2019). As well as preparing appropriate scenarios in a game, technical design processes for reflecting these scenarios in the targeted way emerge as an important issue. For this reason, it is of great importance to consider and plan many components from scriptwriting to technical processes and learning theories in educational digital game design.

\section{Player Types and Game Design}

While educational digital games focus on instructional purposes, fun elements inherent in games are often overlooked. This situation causes students to be disconnected from the game and decreases their motivation and engagement to play and learn (Ike \& Hoe, 2020). It is thought that developing designs suitable for player types will be a good solution to solve the problems related to fun and motivation in educational games (Manero et al., 2016). For this purpose, the game scenario in the study was prepared in accordance with Bartle's (1996) player types, so it was aimed to reveal a game for the players' preferences and interests in playing games. It has been observed that there is limited number of studies similar to this game study in the literature. Busch et al. (2016), is one of the few experimental studies conducted on this subject. They aimed to create an individualized game environment by adapting game mechanics and dynamics according to player types. In the study, two of the 7 player types of BrainHex (achiever, conqueror, daredevil, mastermind, seeker, socialiser, and survivor) and classification, mastermind and seeker player types were compared (Nacke et al., 2014). An experimental study was conducted with 51 students by creating a mobile game that can be adapted to these two player types. In the study, it was aimed to determine the player type from the choices the students made while playing the game. The study revealed that the design included a limited type of player, and the purpose of the game was to test the model created to determine the player type rather than adapting the environment according to the player type.

In the literature, it has been observed that there are multiple types of players (Bartle, 1996; Kallio et al., 2011; Tuunanen \& Hamari, 2012; Xu et al., 2012). Among these, Bartle's (1996) classification is a highly preferred taxonomy (Ferro et al., 2013). In this study, four player types (socializers, achievers, explorers, killers) determined by Bartle (1996) are taken as basis. When socializers interact with other players, they have fun in games. They are happy to collaborate to get better things than they could have done by themselves. The achievers are concerned with the points and their situation in the game. They want to show their friends how they are progressing. They want their points, bonuses, and prizes to be displayed in one corner of the screen. Explorers want to see new things and discover new secrets. They do not care much about points or awards. The reward for them is discovery. The killers are worrying players. The killers want to earn points and status like accomplishers. The killers want to see what other players have lost. In the study, designs were made according to Bartle's (1996) player types in the writing of the scenarios, preparation of characters, objects, and game environment. Due to the development of a game for middle school students, the term "hunter" was used instead of the term "killer" player in the study.

\section{Game Engines Used in Game Development Process}

One of the most important issues to be decided before starting digital game design is to determine the game engine to be used to develop the game. Game engines are software developed to provide convenience to users during game development. There are many game engines that can be used for this purpose. The point that designers should pay attention to before deciding is the advantages and disadvantages offered by the game engine. Unity 3D, Unreal Engine, Corona Labs and GameMaker Studio are among the most used game engines. The advantages and disadvantages of these game engines are given in Table 1. 
Table 1. Advantages and disadvantages of frequently used game engines

\begin{tabular}{|c|c|c|}
\hline Game Engine & Advantages & Disadvantages \\
\hline Unity 3D & $\begin{array}{l}\text { - It can output on different platforms such as Web, iOS, } \\
\text { Android, PC, Game consoles. } \\
\text { - Coding can be done with JavaScript and C\#. } \\
\text { - You can work on the interface with drag and drop } \\
\text { operation. } \\
\text { - The designer community is very large. } \\
\text { - You can become a designer for free. } \\
\text { - There is a large object store. } \\
\text { - There is 2D and 3D development support. }\end{array}$ & $\begin{array}{c}\text { - The graphical interface is complex for beginners. } \\
\text { - Optimization may be a problem in graphically } \\
\text { developed games. }\end{array}$ \\
\hline Unreal Engine & $\begin{array}{l}\text { - Graphics support is high. } \\
\text { - It has a large object store. }\end{array}$ & $\begin{array}{c}\text { - Since the coding language is } \mathrm{C}++ \text {, it requires more } \\
\text { programming knowledge than other languages. } \\
\text { - Limited third-party API support. } \\
\text { - It is problematic to operate on low specification } \\
\text { devices. }\end{array}$ \\
\hline Corona Labs & $\begin{array}{l}\text { - There is support for 2D game development. } \\
\text { - It uses Lua coding language, which is easier to learn for } \\
\text { beginners to code. }\end{array}$ & $\begin{array}{l}\text { - There is no support for 3D game development. } \\
\text { - Community support is limited. } \\
\text { - Printouts can only be made for mobile operating } \\
\text { systems. }\end{array}$ \\
\hline GameMaker Studio & $\begin{array}{l}\text { - It is easy to use. } \\
\text { - It is ideal for those with limited programming } \\
\text { knowledge. } \\
\text { - Suitable for simple projects }\end{array}$ & $\begin{array}{l}\text { - It uses its own programming language. } \\
\text { - Programming features are limited. } \\
\text { - There is no support for 3D game development. }\end{array}$ \\
\hline
\end{tabular}

When the game engines used for game development were examined, it was decided to use the Unity 3D program in the study due to the advantages it provides. Output for web, iOs, Android, PC and game consoles, the ability to adjust the most appropriate graphics performance between devices, to code with JavaScript and C\#, comfortable working on the interface, to have a lot of objects in the object store, 2D and 3D development support are the most important reasons for choosing Unity 3D (Labschütz et al., 2011). Although the graphical interface is complex for beginners, Unity 3D program provides many advantages among professional game engines (Vasudevamurt \& Uskov, 2015).

\section{Purpose of the Study}

The educational digital game designed in the study was developed within the scope of the TÜBITAK $1001118 \mathrm{R} 034$ project titled "Developing a Game-Based Adaptive Environment for Programming Instruction for Middle School Students and Investigating the Effect on Students' Computational Thinking Skills". Within the scope of the project, it was aimed to design an educational game to explain how data is processed on the computer and the tasks of the hardware units before starting the programming education. For this purpose, in this study, an educational digital game for different player types was designed to teach the role and data transmission of hardware units in the 5th and 6th grade information technologies and software lesson curriculum. Research questions in the study conducted within the framework of this purpose are as follows:

1. What are the stages in the educational digital game design process developed according to the player types?

2. What are the studies done in the process of planning the game design?

3. What are the studies done in the $3 \mathrm{D}$ game design process?

\section{METHOD}

\section{Research Method}

The study was conducted with the developmental research method Type1 which is one of the design-based research methods. Developmental research method Type 1 studies focus on the development of a specific educational product, program, process, or tool (Kuzu et al., 2011; Richey \& Klein, 2005). This type of research focuses on determining general design principles or making suggestions for design processes. Type 1 studies include the evaluation process as well as product design and development. It is possible to work with different participants in the design, development, and evaluation processes of a Type 1 study. Richey and Klein (2005) stated in the Type 1 research, designers, developers, users, evaluators, and experts could be participants in the design and development phase. He stated that users (designers, developers, teachers, etc.) and experts could take part in the evaluation phase. In Type 1 studies, data collection techniques such as interviews, observations and document analysis are used. The gamebased adaptive system discussed in the current study, is a part of the system prepared within the scope of the project. Although different game design models have been used in the study, the developed game-based adaptive system is not just a game module. It is also an educational material suitable for specific student groups as the game was developed in the light of participation and evaluations of the experts in different fields. The method of the study is given in Figure 1. 


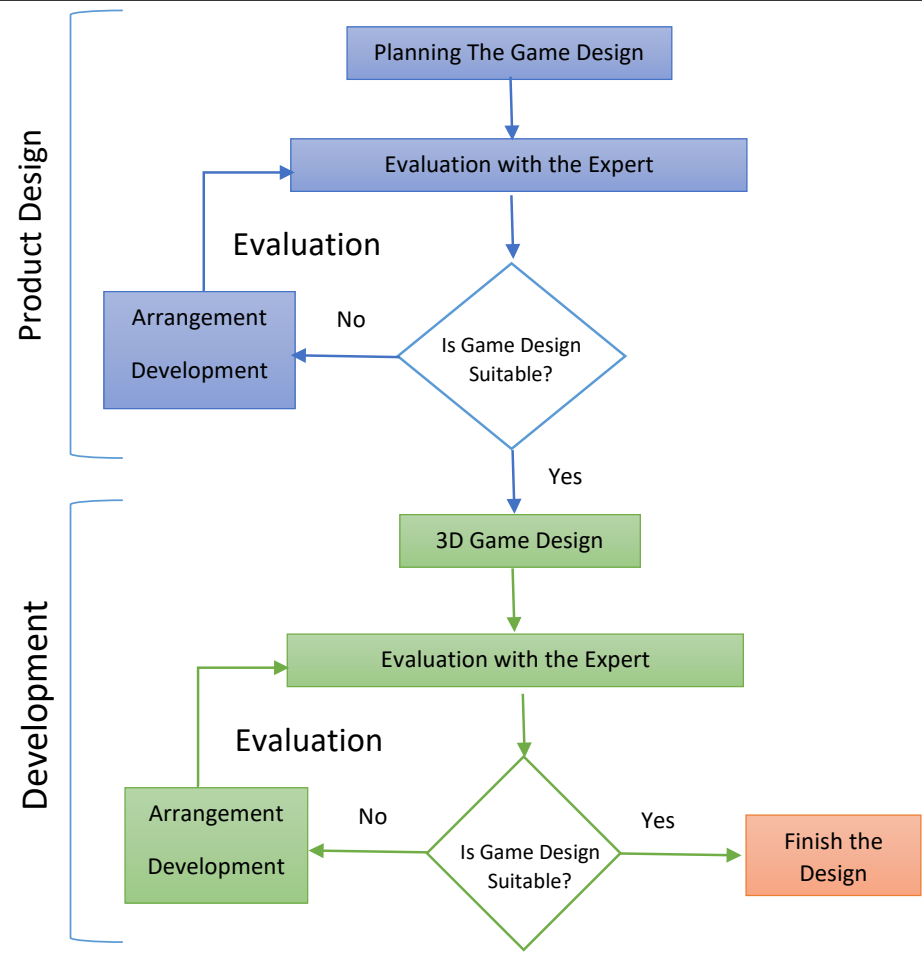

\section{Figure 1. Research method}

The product design and development phase of the study were carried out by 4 researchers. The game design was planned in the product design phase. 3D game was designed in the development phase. In the evaluation phase, the studies done during the product design and development phase were evaluated. Throughout the process, the product design, development, and evaluation cycle have been continuously applied. During the product design and development phases, revisions were made when needed and the process was re-evaluated.

\section{Project Team}

A team of field experts took part in the design, development, and evaluation phases of the project. The design and development phase were carried out by 4 experts (E1, E2, E7, E12), while the evaluation phase was carried out by the entire project team. The experiences and fields of expertise of the evaluation group members are given in Table 2.

Table 2. Evaluation team in the game design process

\begin{tabular}{|c|c|c|c|}
\hline Code & Degree & Experience & Fields of Expertise \\
\hline E1 & Prof. Dr. & $\begin{array}{c}\text { He has } 28 \text { years of experience as an } \\
\text { academic. }\end{array}$ & $\begin{array}{l}\text { Intelligent tutoring systems, special education, design of } \\
\text { learning environments and content development }\end{array}$ \\
\hline E2 & Prof. Dr. & $\begin{array}{l}\text { He has more than } 30 \text { years of } \\
\text { experience as an academic. }\end{array}$ & Design-based research, qualitative research, interface designs \\
\hline E3 & Prof. Dr. & $\begin{array}{l}\text { He has more than } 30 \text { years of } \\
\text { experience as an academic. }\end{array}$ & Educational software and mathematics education \\
\hline E4 & Prof. Dr. & $\begin{array}{l}\text { He has more than } 30 \text { years of } \\
\text { experience as an academic. }\end{array}$ & $\begin{array}{c}\text { Artificial intelligence, programming, problem solving, intelligent } \\
\text { teaching systems }\end{array}$ \\
\hline E5 & Assist. Prof. Dr. & $\begin{array}{c}6 \text { years Teacher, } \\
\text { He has } 11 \text { years of experience as an } \\
\text { academic. }\end{array}$ & $\begin{array}{l}\text { Intelligent tutoring systems, adaptive learning systems and } \\
\text { programming teaching }\end{array}$ \\
\hline E6 & Assist. Prof. Dr. & $\begin{array}{l}\text { He has } 10 \text { years of experience as an } \\
\text { academic. }\end{array}$ & $\begin{array}{l}\text { Distance education, e-learning, special education technologies } \\
\text { and content development }\end{array}$ \\
\hline E7 & Lecturer Dr. & $\begin{array}{c}11 \text { years Teacher, } \\
\text { She has } 4 \text { years of experience as an } \\
\text { academic. }\end{array}$ & $\begin{array}{l}\text { Gamification, educational games, game-based learning, } \\
\text { instructional design, and content development }\end{array}$ \\
\hline E8 & Lecturer & $\begin{array}{c}\text { He has } 12 \text { years of experience as an } \\
\text { academic. }\end{array}$ & $\begin{array}{c}\text { Virtual worlds, programming, content development and coding } \\
\text { education }\end{array}$ \\
\hline E9 & Lecturer & $\begin{array}{c}\text { He has } 6 \text { years of experience as an } \\
\text { academic. }\end{array}$ & $\begin{array}{l}\text { 21st century skills, computational thinking, unplugged coding } \\
\text { activities, content development }\end{array}$ \\
\hline
\end{tabular}




\begin{tabular}{|c|c|c|c|}
\hline Code & Degree & Experience & Fields of Expertise \\
\hline E10 & Research Assistant & $\begin{array}{l}\text { She has } 4 \text { years of experience as an } \\
\text { academic. }\end{array}$ & Content development \\
\hline E11 & Teacher-PhD Student & $\begin{array}{c}\text { He has } 14 \text { years of experience as a } \\
\text { teacher. }\end{array}$ & $\begin{array}{c}\text { Game-based learning, coding education and content } \\
\text { development }\end{array}$ \\
\hline E12 & Master Student & - & Computer Education and Instructional Technology \\
\hline E13 & Master Student & - & Computer Education and Instructional Technology \\
\hline E14 & Master Student & - & Computer Education and Instructional Technology \\
\hline
\end{tabular}

E: Expert

\section{Data Collection}

The data were collected through audio recordings taken at the project meetings and the researcher diaries kept during the phases. During the project meetings, evaluations were made regarding the whole process such as the scenario of the game, suitability to player types, and the design of the game. Expert opinions on the evaluation of the game and the design process were collected by audio recordings. The data in the audio recordings were transcribed for content analysis.

Another data collection tool was the researcher diaries. The evaluations of the experts and their opinions about the arrangements to be made in the design were noted in the researcher diaries. One of the researchers (E12) who carried out the implementation in the study took notes throughout the process. Information about the meeting date, evaluations, and arrangements to be made were noted in the diaries, too.

\section{Data Analysis}

The data collected from the audio recordings were analysed by content analysis. Cohen, Manion, and Morrison (2017) stated that content analysis reveals the common themes occur in the written data. Content analysis is an effective analysis method in organizing, classifying, comparing texts, and producing theoretical results from texts (Yıldırım \& Şimşek, 2008). As a result of the analysis, thematic codes were spotted from the expert evaluations. These codes were supported by quoting the experts, which were presented under the evaluation category. In addition, the notes taken about the arrangements to be made in the researcher's diaries were arranged and associated with the codes that emerged. The findings obtained regarding the regulations to be made were given under the correction category.

\section{Educational Game Design Process}

The game designed in the study was created by examining many different game design models and frameworks in the literature. Although the game design models discussed have different features, they have been selected according to the aims of this study which considers the features of the subject, the level of the students and the factors that can be used to individualize the environment. In Level-Up (Eagle, 2009), one of these game designs models, learning was modelled based on students' log records. In this way, it was aimed to determine the learning deficiencies of the students. Aleven et al. (2010) emphasized that the success of educational games will be higher by associating game mechanics, game aesthetics and game dynamics in order to achieve learning goals in the framework they created for educational game design and analysis.

Tan et al. (2007) developed an adaptive digital game-based system and proposed an individualized model that analyses the data they receive from users. Game elements such as story, goals, and challenge that make up a game were used to adapt the model. Annetta's (2010) framework for educational games is based on the constructivist approach in which students build their own knowledge by combining their new experiences with their previous experiences. In this way, it was stated that the game designs should be developed by adding on the previous knowledge at every level and should be related to daily life.

On the other hand, Shi and Shih (2015) presented a comprehensive design proposal consisting of 11 factors (game goals, game fantasy, game mechanism, game value, narrative, interaction, challenges, freedom, sociality, sensation, and mystery) in the gamebased learning design model they developed using game mechanics and dynamics. It was stated that the game type alone is not enough, so a motivating and interesting game environment should be arranged according to these 11 factors in order to facilitate the learning of the students during the game. In this study, the features of the game design models mentioned above were used in the design and development process. Therefore, a game-based adaptive environment was prepared according to player types. In the current study, inferences were made for the creation of an individualized educational game environment with game mechanics and dynamics by keeping track of students' learning from log records. In addition, with the game-based adaptive system, it was aimed to make use of analogies in the scenario and visual designs of the students to build their new knowledge on their previous experiences and to provide them a meaningful learning environment with a constructivist approach.

The study was carried out in 3 phases according to the design-based research Type 1 . These are Product Design, Development and Evaluation phases. The game design was planned in the Product Design phase (Stage I). The processes of 3D game design were carried out during the development phase, and this phase included 2 sub-stages (Stage II and Stage III). The Evaluation phase was carried out continuously in both the product design and the development phases. In the first stage, the problem was determined, the game scenario was prepared according to the goals in the curriculum and the types of players and scenario drawings were

| Kastamonu Education Journal, 2022, Vol. 30, No. 1 | 
made (Product Design). In the second stage, the game was designed in 3D. At this stage, the game engine to be developed and the technical features to be used in the game were determined, and the graphical elements to be used in the game were created; the general design of the game environment, the placement of the objects, and the creation of the animations in the game were made. In the third phase, the interface design, as a continuation of the development phase, and instruction and feedback designs were made (Figure 2).

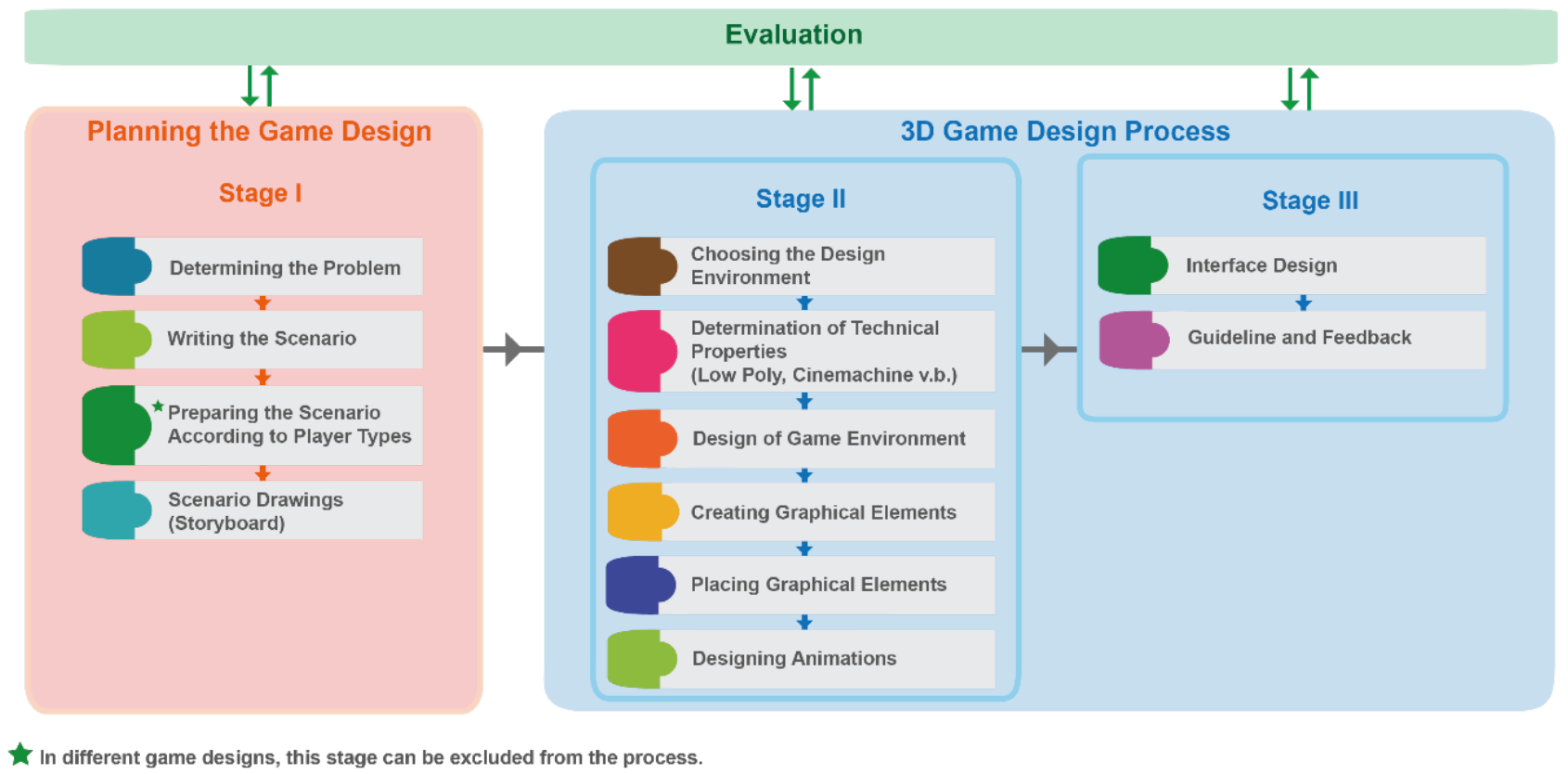

Figure 2. Educational game design process

To achieve the purpose of the study, the game design was planned by considering different player types. In some other studies which only focus on developing a game without regarding different player types, this step is generally skipped. All three stages in the game design process were evaluated in detail by the project team who made necessary corrections at each stage and moved to the next stage. During the process, interim evaluations were also made by the project team making necessary corrections. Finally, the game was designed.

\section{Planning the Game Design (Product Design)}

\section{Stage I}

\section{Determining the Problem}

The game developed within the scope of the project was designed to teach how data is processed on a computer before starting programming education. The aim of the game was to teach students the functions of the hardware's in the computer and how the data is transmitted in the mainboard. Subjects for the content of the game were selected according to the goals in the 5th and 6th grade curriculum of MEB Information Technologies and Software course. The hardware units, whose tasks were described in the game, were the motherboard, processor, hard disk, ram, display card, and power supply.

\section{Writing the Scenario}

After determining the subjects for the content of the game the project team decided to design a story-based scenario. For this reason, the events that will take place in the scenario were determined first, and then the scenario was narrated by 4 researchers and converted into text format. In the story-based scenario, the team decided to make the internal of computer case look like a city. The internal of the computer case included buildings in a city, to explain the functions of the hardware units to the players (students) better and to make abstract concepts more concrete. The processor was resembled to the assembly building, the RAM seemed to be a storage area, the Hard disk was likened to hangar, the Video Card resembled to a TV studio, the Ethernet card was likened to bus terminal, and the Power Supply was likened to power plant. 


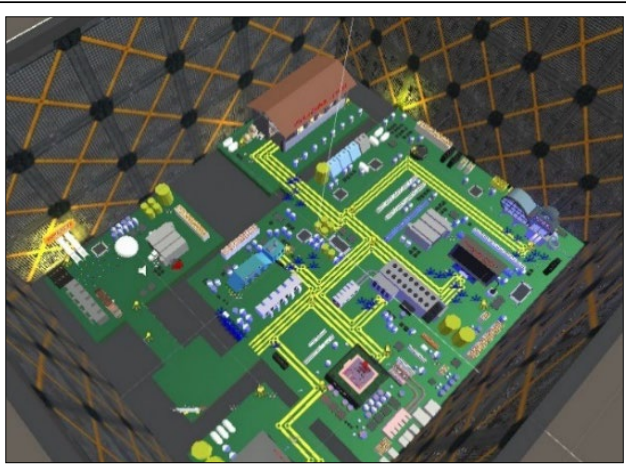

(a)

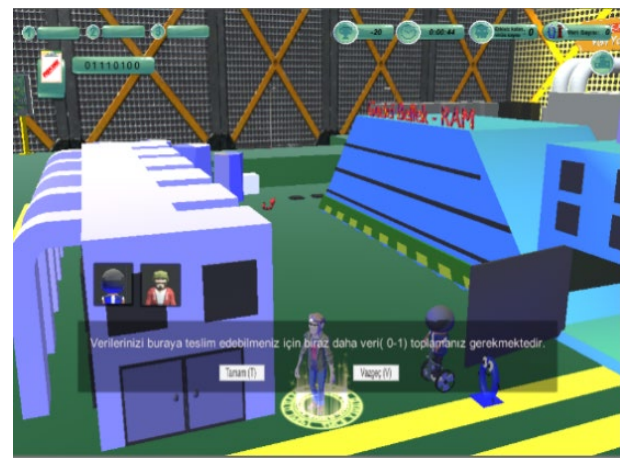

(b)

\section{Figure 3. The internal of the computer case designed like a city}

According to the scenario, a child who wants to do his homework on the computer learns how the data is transmitted in the hardware units with a character that can enter the safe. Players will be able to play the game by ensuring that the character in the safe collects data and transmits it to the hardware units in the appropriate order. In the game scene, the player first sees the area on the screen where the data is modelled as 1 and 0 coming from the keyboard and mouse buses. In this area, there is a screen with objects that the player can use to collect data. The player can choose from auxiliary objects from this screen. These objects were prepared according to Bartle's (1996) player types. The player takes the collected data to the correct hardware units and earns points during this time. When the player reaches the relevant unit, he will be able to learn the tasks of the unit from the information plates located in front of the units (Figure 3b). If the player performs their tasks in each unit correctly, they will be able to deliver their data. If the player goes to the wrong unit, he will be directed to the correct units with the feedback in the game. Each time the player goes to the correct unit, he will gain points.

\section{Preparing the Scenario According to Player Types}

One of the most important points of game concept is that not all players are the same, and there are features that will appeal to different player characters in a game (Bozkurt \& Genç Kumtepe, 2014). The different preferences of individuals in a game are explained by the player types. The difference in game preferences is one of the situations that affect the players' motivation to play. Therefore, the designs were made in the current study by considering the player types, and the scenario in the designed game was prepared according to Bartle's (1996) four classification of player types. By preparing the games according to the player types, it was aimed to take the game preferences of the students into consideration, thus making the games more motivating and instructive. Considering other the educational game design processes, taking into account these four player types make the current study different from other studies which disregard player types.

The basic scenario features are the same in the game, which was prepared to teach the transmission of data on the computer and the tasks of the hardware units, and different features suitable for each player type were added to the scenario. The game mechanics used in the game scenario in accordance with the player types vary. These game mechanics, time, points, quests (the way of collecting points), gifting (the accessories that the player will use), challenges (the way they reach the hardware units in the game area), narration, badges, gifting, and leaderboard. Each player can play the game using features suitable for their own player type. There are features suitable for four player types in the whole game, and players can play the game with the game mechanics for the player types they want with the choices they make, and they can change their choices at any time. The scenarios prepared in accordance with the player types were examined by the project team, the necessary arrangements were made, and the scenarios were finalized. An example of how the game environment differs according to player types is given in Table 3. 
Table 3. Game scenarios adapted according to player types

\begin{tabular}{|c|c|c|c|c|}
\hline $\begin{array}{l}\text { Player } \\
\text { Type }\end{array}$ & $\begin{array}{l}\text { Player Type } \\
\text { Preferences } \\
\end{array}$ & Game Mechanics & $\begin{array}{l}\text { Adapting the Scenario According to the } \\
\text { Player Type }\end{array}$ & Screenshot in Game \\
\hline 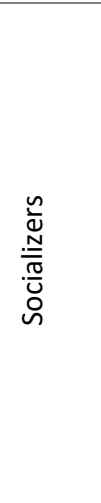 & $\begin{array}{c}\text { - Communication } \\
\text { oriented } \\
\text { - Collaborate with } \\
\text { other players } \\
\text { - Likes to chat } \\
\text { and make other } \\
\text { players } \\
\text { successful } \\
\text { - Helpful }\end{array}$ & $\begin{array}{l}\text { - Point } \\
\text { - Gifting } \\
\text { - Badges } \\
\text { - Leaderboard } \\
\text { - Gifting }\end{array}$ & $\begin{array}{l}\text { Since the socializer type players attach } \\
\text { importance to communication and } \\
\text { cooperation, designs were made to meet } \\
\text { these characteristics in the scenario. } \\
\text { Since the socializer player type has the } \\
\text { characteristics of a social person, the } \\
\text { avatar who collects points in the game } \\
\text { will be given a headset. Headphones, } \\
\text { microphones, and antennas that the } \\
\text { avatar can use were designed for } \\
\text { socializer players, and screens were } \\
\text { created where the avatar could } \\
\text { communicate with the player. }\end{array}$ & \\
\hline
\end{tabular}

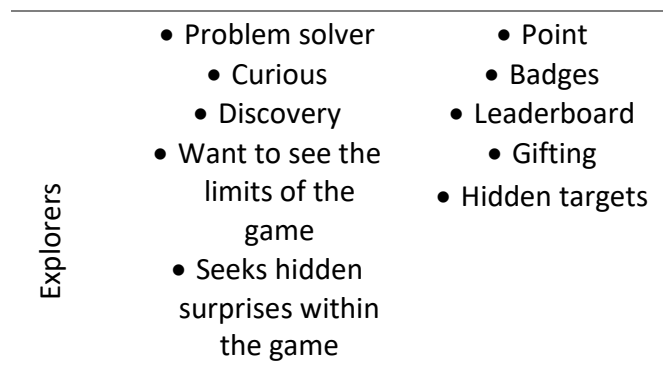

Since the explorer player type focuses on exploring, these players have been enabled to fly around on the motherboard and explore all units and fulfil the assigned tasks in this way. In the explorer player type, the player can also see the units he reaches on the map. A magnifying glass, binoculars, camera, and a rocket to help fly are designed for explorers to navigate the motherboard and collect prizes

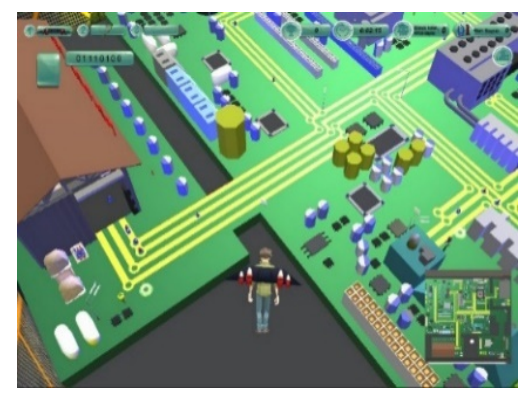

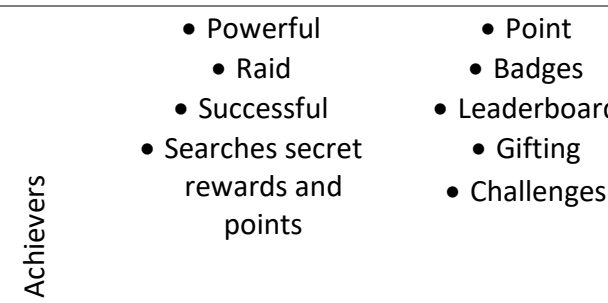
Achiever player type attach importance to game mechanics such as awards, points, and ranking. Since it is important for those who achieve to collect a lot of points in a short time, a time limit has been added to the game. Elements that will earn extra points are also added to the game for achiever player type. The reward bag and glasses objects are designed to help achiever player types collect the rewards in the game.

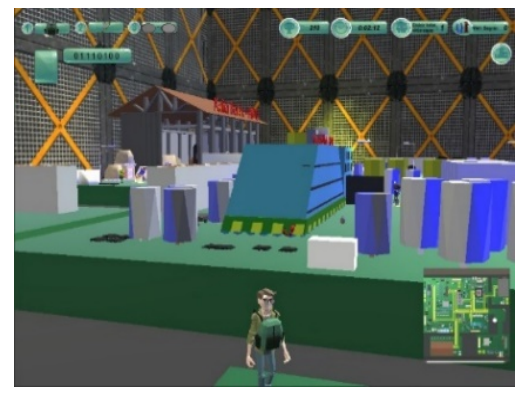

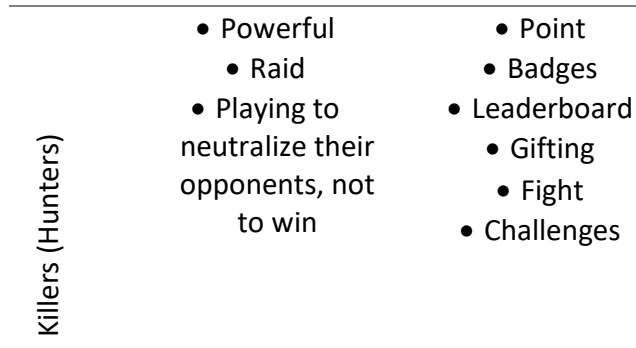

\begin{abstract}
The hunter player types want to win against the opponent or destroy the objects in the game. For this reason, there are various types of viruses that circulate freely inside the motherboard and can be destroyed by the player. The player earns points for destroying these viruses. Hammer, shield, lightsabre, slingshot objects that can be used in the game are designed for hunter player types.
\end{abstract}

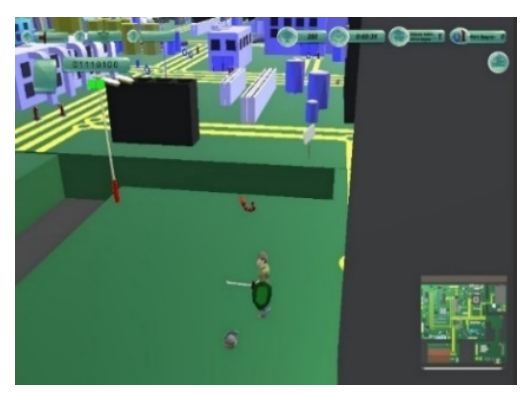

\title{
Scenario Drawings (Storyboard)
}

Before starting the 3D design phase, the storyboards of the game scenarios were prepared (Figure 4). These drawings, which are referred to as visual designs (storyboards), enable game designers to present the events in a holistic framework, to integrate different aspects of the game and to show them concretely. Visual designs can show the whole of the characters, places, and objects in the game. With these drawings, it becomes easier to shape the appearance of the game, and it is understood in what kind of world the player will interact with the characters and the interface (Soyluçiçek, 2019). In addition, visual designs enable experts and designers in the game design team to construct events more easily, allowing experts to better understand the process and to make necessary interventions.

In the current study, although the scenarios were adapted according to player types, it was aimed that the player transmits data on the motherboard and understand the working logic of the hardware units in each game. For this reason, the main events 
in the game setup were generally explained in the scenario drawings. With the drawings, the regulations for the scenario in the game design process were made easier by the project team, and the designers realized the design process more easily.
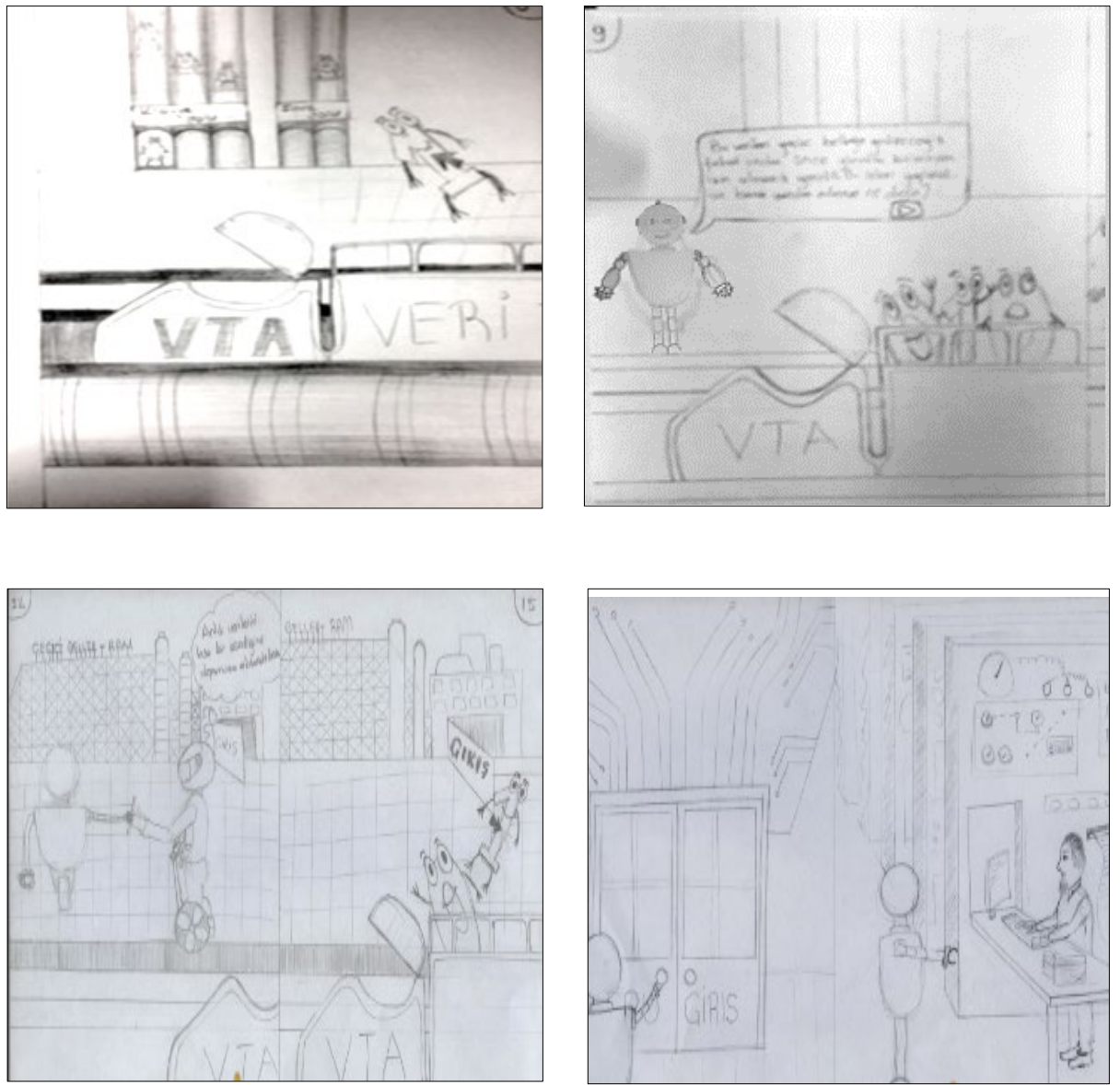

Figure 4. Examples of storyboard

\section{D Game Design Process (Development)}

After the game planning process was completed, the digital design process of the game started. The development stages of the game in digital environment are given in Figure 5.

In the 3D design process, graphical elements were started to be created first. For this purpose, both the characters and the objects to be used in the game were modelled with the modelling program Blender. For the main character selection, a selection was made from the Asset Store in the Unity program. After the graphic elements were designed, these elements were placed in the Unity program. Meanwhile, by adjusting the resolution settings of the objects and characters (Low Poly), the loading problems that may occur during game play have been resolved. With the Recorder plug-in in the Unity object store, screen recording was taken, and animations were created for the interaction of the characters in the game. The project scene was created in Unity by preparing the objects, characters, and animations to be used in the game. In addition, with the codes written on the objects in Visual Studio, the characters were animated and their control in the game was provided. Finally, in-game instructions were created for the player to collect points and perform the correct operation steps in the game, and the feedback to be provided to the player with the score, time, and leaderboard mechanics in the game. With the output of the game in WebGL format, the game has been made playable on the browser. In this way, project outputs can be run on multiple platforms via web browsers without the need for any plug-ins. The 3D design process of the game was given in detail below. 


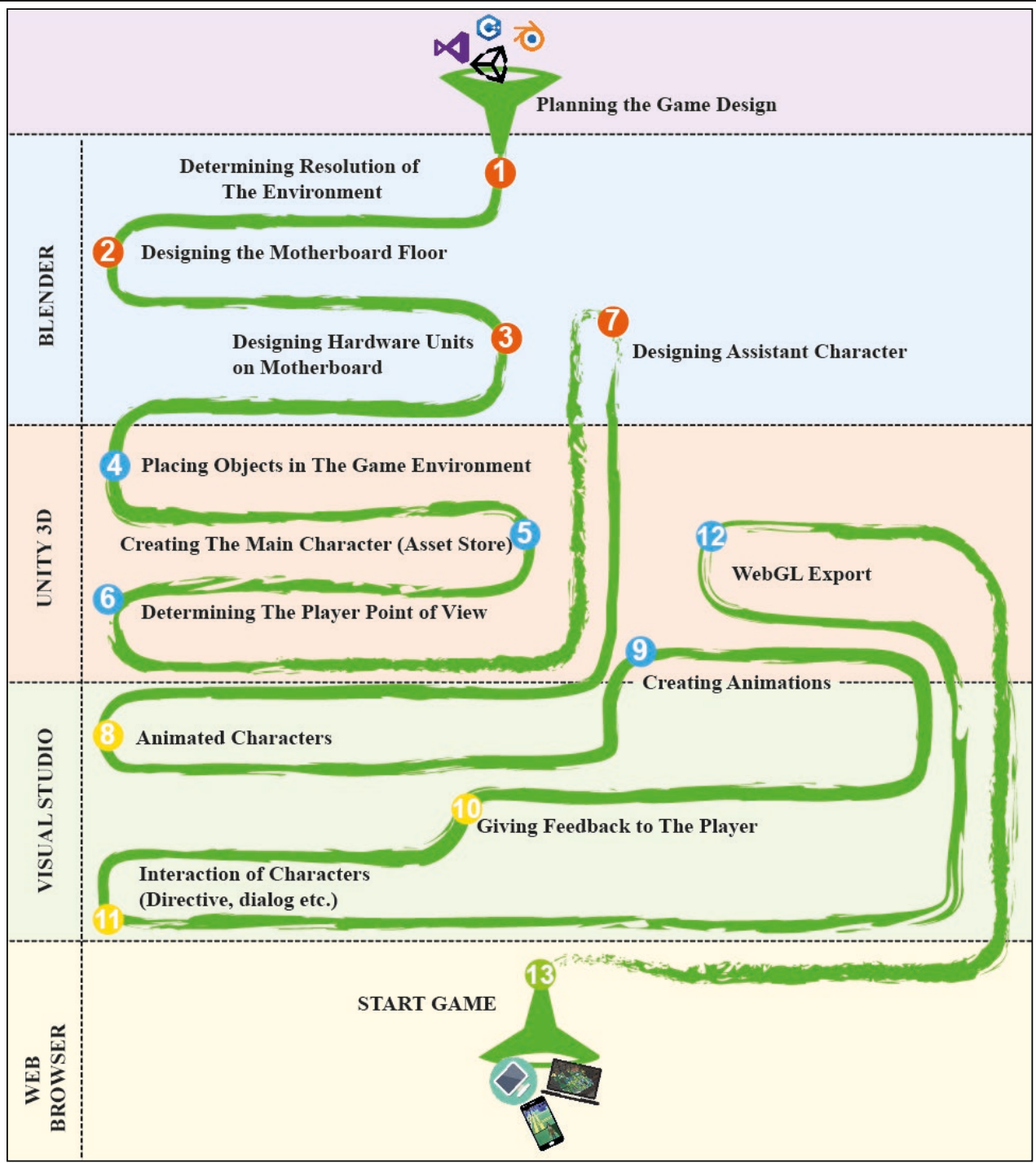

Figure 5. 3D game design process

\section{Second Stage}

\section{Choosing the Design Environment}

After the planning game process was completed, it was decided to use the Unity 3D program to design the game with the decision of the project team. The advantages and usage reasons of the program were explained in section "Game Engines Used in Game Development Process".

\section{Determination of Technical Properties (Low Poly, Cinemachine)}

Before starting the 3D game design, the technical features required for the design and play of the game have been determined. First, regulations were made for the resolution of characters and objects. LowPoly (low resolution) feature was preferred for resolution of character, object, and environment. The reason why low-resolution designs were preferred was to reduce the waiting times during the loading of games and to ensure their comfortable use on mobile devices.

Since the standard camera in Unity offers limited features to the user, the camera plug-in named "CineMachine" in the object store was downloaded and added to the game environment. The "FreeLook camera" code file available in this package has been applied to the main character. With this camera package, the point of view of the player was directed with the mouse and the player was allowed to play the game from the eyes of the third person. In addition, with the "Collider" add-on added to the camera and other objects, the camera was prevented from entering the objects in the environment, allowing the main character to zoom in during any collision. With the CineMachine plug-in, more than one camera was added to the scene, and it was possible to switch between these cameras easily and animated.

\section{Design of Game Environment}

A cube object was created to create the ground on which the game will be played, and this object was given the image of a motherboard. Data buses that allow communication of circuits and hardware units were prepared on the motherboard. In order 
to transfer these buses to the game environment and to create a realistic image, a plug-in called "Displace" was used and added to the motherboard.

\section{Creating Graphical Elements}

In order to create 3D models to be used in the game, object and character designs were made in the Blender modelling program. In addition to the modelled objects, Unity object store (Asset Store) was also used for main character and object selections. Examples of the objects used in the game are given in Figure 6.

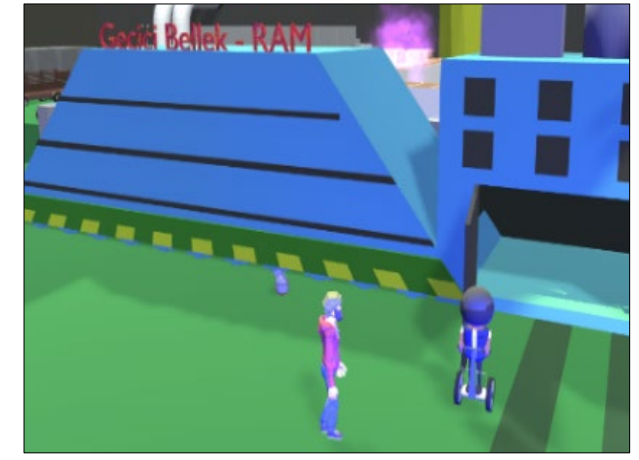

(a)

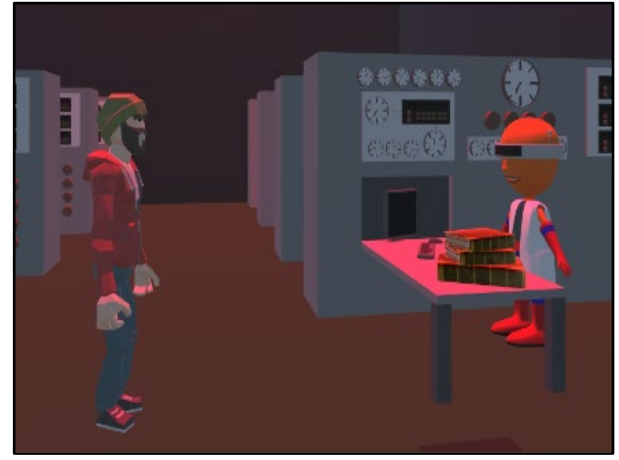

(b)

Figure 6. Examples of objects and characters used in the game

The hardware units in the game were compared to the buildings in a city (Figure 6a). These buildings and assistant characters working in these buildings were developed in the Blender program (Figure 6b). In the design of objects such as buildings and officer characters, the design was made by considering the characteristics of the hardware's.

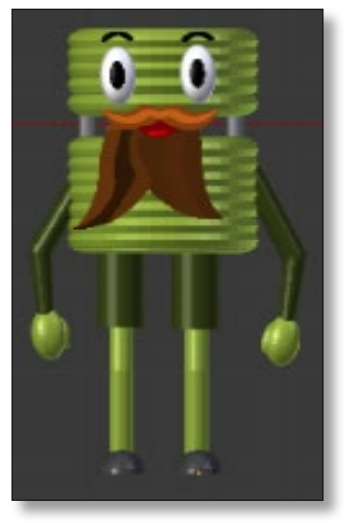

(a)

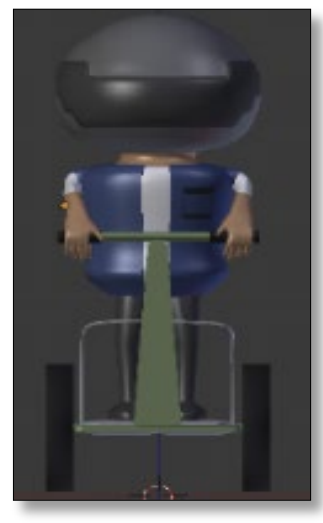

(b)

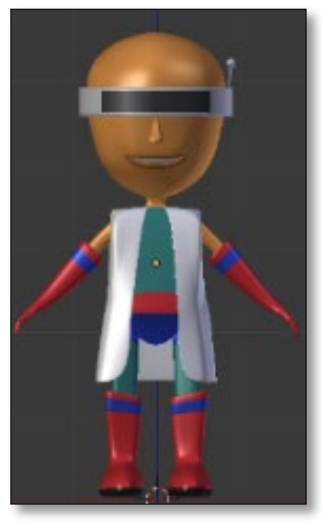

(c)

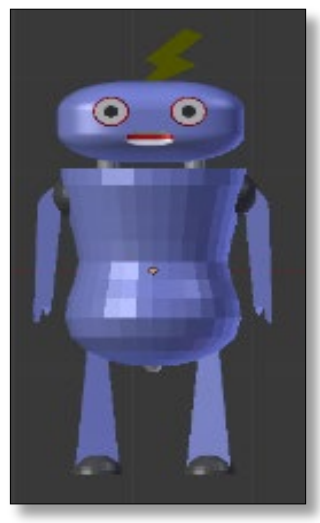

(d)

Figure 7. Characters in charge of hardware units

The character in charge of the hard disk unit has been drawn like oval lines and disk structure, in a way to remind the physical structure of the hard disk (Figure 7a). The character is in front of the hard drive and when the main character arrives, it gives information about the hard drive. In addition, it helps to deliver the data by checking whether the necessary permissions have been obtained from the processor unit. The attendant in the ram memory unit was designed as a character that moves quickly with his vehicle, since the operations are performed fast, and it is a temporary data storage unit (Figure 7b). This character also checks whether the main character receives a license from the processor while transmitting the data to the ram memory. Since the processor is in the manager position on the motherboard and allows for all operations to be performed, the manager in this unit, wearing apron and glasses, is designed as a chef-shaped character (Figure 7c). The task of this character in the processor is to create the necessary permission document for the main character in the game to deliver the data collected to the units. Finally, the duty plug in the power supply was designed as a plug (Figure $7 \mathrm{~d}$ ). This officer was designed to help the main character find the problem and continue the game by solving the problem in the power outage due to the scenario.

\section{Placing Graphical Elements}

While designing the game environment, keyboard and mouse buses were placed in a corner of the case as a representation. These buses were used to send commands sent by the computer user from the keyboard or mouse to the computer. Since the

| Kastamonu Education Journal, 2022, Vol. 30, No. 1| 
commands are processed according to the number system 1 and 0 in the computer, the data coming from the buses were designed as 1 and 0 . The task of the player is to collect the data coming from the data buses in a vehicle called the "data collection tool" and move it to the units on the motherboard in the correct order. "Collider" extension has been added to the objects so that the character can collect data. Thanks to this add-on, the collision of two objects was checked with the help of the code and the data was directed to the car chassis. Thus, the main character can collect the data in the safe of the data collection tool. After player collecting data, the vehicle must reach the correct unit. Whether the unit that the player goes to is true or false is controlled by various variables. These variables are controlled by the codes written in the Visual Studio program. In this way, when the player takes the data to the wrong unit, feedback is given in the game and the player is directed to reach the correct units.

\section{Designing Animations}

Three types of animations have been created in the game in order to activate, control, and interact with characters and objects.

Movement: Bone structure has been added to the character so that the characters can move in the game. The animations of walking, running, and jumping have been downloaded from the object store, in order to move the bone structure. It was added to the character by editing in the Unity-Animations menu.

Control: In order for the player to move the character, the regulations for the user controls were made in the Visual Studio program. During this regulation, when it is necessary to make an operation regarding the keys to be used to play the game, a code in the form of "Input.GetKey (KeyCode.W)" was used in C \# coding language. Controls such as the ability to move the character used in the game when the W, A, S, D keys were pressed or run fast when pressing the Shift key were carried out using this line of code. With the help of the mouse, necessary interventions have been made with different lines of code to change the perspective of the character and move to that direction when the forward button is pressed.

Interaction: In the game, the main character must establish a dialogue with the unit officers there while collecting data and transmitting it to the relevant units. Animations have been prepared to explain this interaction process to the user. In order to add these animations to the game, the "Recorder" plugin in the Unity object store was used. By adding the codes written in the Visual Studio program to the objects in the animation, interaction is provided. During this interaction, the movements of the characters on the screen were recorded in video format by running the Recorder plug-in. In addition, a chat screen was opened during the dialogue between the main character and the assistant character. This chat screen both guided the player to transmit data to the correct unit in the game and taught the player the tasks of the hardware units. In order to create this chat screen, a dialog plug-in called "VIDE Dialogue" has been downloaded from the Unity object store. In order for this add-on to work, the fields in the game were determined and the "Collider" add-on, a feature of the Unity program, was added to these fields. Thanks to this add-on, which is not seen by the players, when the character enters the specified area, the "private void OnTriggerExit (Collider other) \{\} " function written in the background allows the player to enter that area and run the dialogue plug-in.

\section{Third Stage}

\section{Interface Design}

In the interface design, a screen was designed to show the game time, score, number of data collected by the player, and game mechanics such as the accessories the player chose to collect data. Interface design was made in line with the opinions of field experts. Objects used in interface design have been downloaded from the Unity object store. The 2D interface design was fixed to certain parts of the game screen as shown in Figure 8, with the use of the Canvas plug-in in Unity.

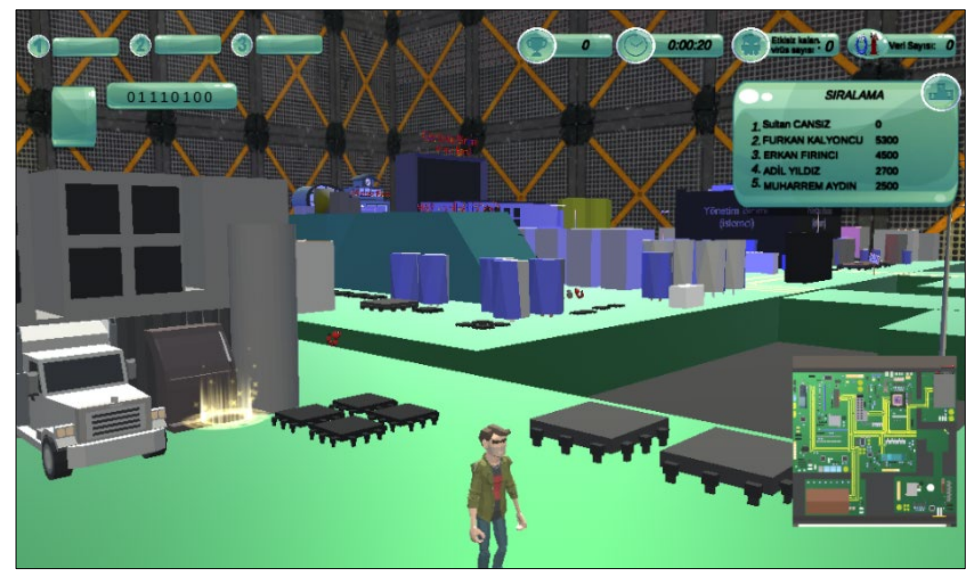

Figure 8. The interface design of the game

\section{Guideline and Feedback}

When the player navigates all the units correctly and completes the tasks, a report window appears. In this report, there are information such as the player's playing time, the number of mistakes, the score he earned. In the game, the instructions, the dialogue system, the report at the end of the game, the time spent in the game, etc. Unity's "Canvas" plugin is used to show the feedback to the player. Canvas plugin is an add-on that allows the user to present content on a 2D screen in the game. This plugin 
is preferred for instructions and feedback to be presented to the player. After the content of the Canvas plugin was created, code was written in the Visual Studio program to determine whether it should be shown and hidden on the screen and at what stages. Thus, it is ensured that the visibility of this add-on is made at the appropriate time in the game.

\section{Evaluation}

The necessary revisions were made in the game with the evaluations made by the experts involved in the project during the design and development phases of the digital game. In the design phase, evaluations were made regarding the application of player types to the game scenario, the structures that the hardware units will be compared to in the city, the accessories to be used by different player types, the rules, and the general story. Findings about the evaluation and correction processes were given according to the design phases. At these phases, evaluations were made for game design and 3D design processes. The evaluations made by the experts about the game design and the corrections made in the first stage are given in Table 4 .

\section{Table 4. Evaluation and corrections made in the first stage}

\begin{tabular}{|c|c|}
\hline Code & Evaluation \\
\hline \multirow{5}{*}{$\begin{array}{l}\text { Student level and } \\
\text { learning outcome }\end{array}$} & $\begin{array}{c}\text { E1: "The hard disk is designed as a hangar. However, the data } \\
\text { storage areas inside can be shown differently to be able to } \\
\text { explain that the data sizes are different." }\end{array}$ \\
\hline & $\begin{array}{c}\text { E6: "Assistant characters describing the mission of the units } \\
\text { have been added to the hardware units." }\end{array}$ \\
\hline & $\begin{array}{c}\text { E7: "A fault caused by an object stuck in the power supply can } \\
\text { be added to explain the function of the power supply in the } \\
\text { case." }\end{array}$ \\
\hline & $\begin{array}{c}\text { E5: "Assistant characters in hardware units can be designed } \\
\text { according to the task and physical characteristics of the } \\
\text { hardware." }\end{array}$ \\
\hline & $\begin{array}{l}\text { E4: "Power outage should be added to the scenario in order } \\
\text { to explain that the data in RAM will be lost." }\end{array}$ \\
\hline
\end{tabular}

- Different box and sack sizes are designed in the hangar.

- Assistant characters on duty have been added to hardware units.

- An animation was prepared for smoke emission as a result of a heating problem with an object stuck in the power supply.

- The characters of the hardware units were designed according to the features of the hardware.

- In the scenario, adjustments were made in which there was a power outage while the player was moving data and the loss of data in the RAM memory was made.

E7: "The features of the accessories that students will choose
should be determined according to the player types"
E8: "Accessories should be designed for the purposes of the
player types in games."
E2: "The variety of accessories for player types should be
increased."
E3: "Accessories should be given by grouping. Accessories of
the same type should be given together instead of being
mixed. "

- The accessories that the character will choose are designed for player types (flying with a rocket, zooming in with binoculars, getting help with a microphone, etc.).

- The variety of accessories considered one for each player type has been increased. The number of 12 designed accessories has been increased to 26 . Accessories of the same kind were given together.

E1: "When the game is over, information about the player's process in the game should be shown."

- The time to finish the game was recorded and reported to the player at the end of the game.

E5: "The time spent in the game, the remaining lives of the player, the number of data collected, the points should be kept and presented to the student at the end of the game."

Game Elements
E5: "The roles of the shortcut on the keyboard used in the game must be specified on the screen."

E6: "The instructions in the game must correspond to the game flow. Some of the instructions don't come with the tasks of the hardware units. "

E9: "The number of data the player collects should decrease and there should be a rule to end the game."
- The interface that indicates the instructions for the game and the functions of the keys on the keyboard has been prepared.

- By using variables in the background, the instructions were arranged according to the game flow.

- The game restarts automatically when the number of data the character has drops to 0 .

The second phase of the process has started in the 3D development phase of the game. At this phase, evaluations were made regarding the way different player types collect points, the duration, the tasks of the accessories used by different player types, the way the player reaches the units in the game, and the game design of the characters (Table 5). 
Table 5. Evaluation and corrections made in the second stage

\begin{tabular}{|c|c|}
\hline Code & Evaluation \\
\hline $\begin{array}{l}\text { Player } \\
\text { Types }\end{array}$ & $\begin{array}{c}\text { E6: "In order for the game to be prepared for different player types, the } \\
\text { choices each player will make while playing the game must be different. } \\
\text { The choices the player makes must vary according to the player types. } \\
\text { Instead of preparing different scenarios, it would be better to give } \\
\text { player types in a single game." }\end{array}$ \\
\hline
\end{tabular}

E1: "When the character passes buildings, he must not go through the walls."

E1: "There is a problem in opening the videos for the officers of the hardware units."

U5: "Once the character and the virus come into contact, it would be more appropriate for the virus to follow the character throughout the

Interaction game and reduce the data collected."

E7: "In the data collection tool, the player should be able to carry as much data as he wants."

E2: "Data should not be transferred to the data collection tool one by one, data should be transferred automatically."

E6: "There are difficulties in transferring the data collected by the character to the data collection tool. Data is not collected in the safe"

E1: "Player point of view should be through the character's eyes."

E8: "Games are usually played with the character's point of view."

E7: "Viruses must be in different shapes. A design should be made for the varieties described in the curriculum."

E1: "When the character comes into contact with viruses, they do not disappear completely, they become ineffective."

Characters

E5: "Viruses can come back to life after a certain period of time after they become ineffective."

E4: "Permission must be obtained from the processor before transferring data to each hardware unit."

\section{Correction}

- The basic task of each player in the game is the same, and the game elements such as the way the player performs this task in the scenarios and the way they collect points were prepared according to the player types.

- Physical properties of all the objects on the motherboard have been given to each other and the problem of objects getting into each other has been fixed.

- Internet browsers have been made compatible with the version of the Unity 3D program.

- Interaction areas of characters and viruses have been updated. When the character can move away from the virus at a certain distance, it leaves a virus tracking.

- Instead of moving the data to the data collection tool one by one, the data was automatically transferred to the data collection tool by the main character touching the data.

- It was ensured that the data collected by the character were collected in the tool chassis using the location features.

- In the first stage, the camera angle was next to the character. In the second stage, the player was allowed to play the game from the eyes of the third person.

- Designs were made to suit different types of viruses.

- When it comes into contact with viruses, it is made ineffective instead of disappearing.

- It was ensured that the inactivated viruses remained inactive for a certain period of time and then took action again.

- Allow the player to get permission from the processor before transmitting data to each hardware unit.

In the third stage of the design process, evaluations were made about the interaction of the characters with each other, and the dialogs displayed on the screen (Table 6).

\section{able 6. Evaluation and corrections made in the third stage}

Code Evaluation $\quad$ Correction

E3: "The texts come in mixed order during the dialogue between the character and the officers in the units."

E9: "In case the collected data is lost, the total number of data collected by the character should not be reduced."

Feedback /

Guideline
E1: "When the main character and the virus touch each other in the game, the decrease in the data and the score will be more suitable for the player type."

E2: "All variables must be reset when there is a power outage in the game scenario."

E7: "The player should be bound by a rule to deliver the data he has to the units."
- During the conversations of the character with the unit officers, it was ensured that the texts fit the dialogue flow.

- By tracking the data falling on the ground, it was ensured that the character was dropped from the total number of data it had.

- With the updates made in the animations prepared for viruses, it was ensured that the player lost data and points in data loss.

- According to the scenario, when there is a power outage in the game, all the data and points of the character are deleted.

- It is ensured that no data is delivered to any unit unless a certain amount of data is collected. 
In the first stage of the design process, evaluations were made about student level and objectives of the subject, player types and game elements. Game elements arranged for player types in the scenario; time, point collection, access to accessories and equipment units. In the second stage of the design process, interactions, characters, data collection and score evaluations were made for the 3D game design process. In this context, evaluations were made on the interactions of objects and characters, the tasks and interactions of accessories designed for player types, the design of the characters, the interaction of the assistant characters in the hardware units with the main character. In the third stage of the design process, data and point collection methods, evaluation and arrangements for dialog windows were made.

\section{DISCUSSION AND CONCLUSION}

In this study, the design process of an educational digital game was carried out with a developmental research method. At the end of the study, how an educational digital game setup is designed according to player types, the stages of the design process, and the studies done in the design process with Unity 3D were determined. In order to complete the shortcomings of classical teaching methods, it is stated that digital games, one of the alternative teaching methods, are effective in learning and more studies should be done in this field (Güler \& Erdem, 2014). In the study, while the stages of game design such as game subject and scenario were carried out in educational digital game design, the scenario was designed for the player types in order to provide the motivation and fun of the players. As a matter of fact, Ike and Hoe (2020) stated that educational digital games are preferred because the fun element inherent in the game meets the psychological needs of students and provides behavioural change. For this purpose, a design aiming to increase loyalty to the game by keeping player preferences at the forefront has been developed in this study. In addition, the preparation of the scenario according to the player types in the study led to the realization of different design studies in the Unity program. The adaptation of educational games according to player types to increase motivations of the students has become more popular with studies in recent years (Bontchev \& Georgieva, 2018; Streicher \& Smeddinck, 2016). Similarly, Malva et al. (2020) developed an educational game for primary school students to develop computational thinking skills that include abstract and conceptual information. In this game, an individually adaptable design was developed in order to attract the attention of each child, and positive results were obtained for the children at the end of the study. For this reason, the design process of the current study serves as an example in terms of both making the game design and showing how this setup can be designed technically.

During the game design process, the game scenario was written by four experts, and the project team made evaluations in terms of the suitability of this scenario to the student level and target achievements, the suitability for the player types and the use of the game elements. In the study, after the scenarios were prepared in accordance with the objectives specified by the Ministry of National Education, these scenarios were arranged according to the characteristics of Bartle (1996) player types. Although the preparation of the scenario according to the player types is a design specific to this study, it is seen as an important issue for an educational game. Educational digital games are preferred because of their motivation, fun, active participation, and interest in educational environments (Byun \& Loh, 2015; Ronimus et al., 2014; Sung \& Hwang, 2018). However, it is stated that the features that make the game play are moved away with faulty scenario designs or scenario and environment designs that are only focused on learning that do not attract the attention of the players (Prensky, 2001). In addition, to prevent the advantages offered by digital games to educational environments from turning into disadvantages, care should be taken to keep the game components such as goal, purpose, rule, scenario, interaction, and fun in balance (Bağcı \& Çoklar, 2014; Devary, 2008). With the preparation of the game scenarios according to the player types, it was ensured that a game design was created for the personal preferences of the students without leaving the fun.

In the process of designing with the Unity 3D game engine, it has been observed that the design of the characters, the interaction of the characters and objects in the game with the player, the design of the points that the player will collect and the way to collect points are important. The visual design program Blender was used for the design of the 3D objects in the game, and the Visual Studio program was used to perform animation and interactions. Interoperability of the game engine and the utilities used in digital game designs and ensuring program compatibility is an important issue to be considered. As a matter of fact, Indraprastha and Shinozaki (2009) stated in their study that the Unity 3D game engine is software that can be used comfortably in creating an interaction system, supporting the object-oriented programming language and the use of different programs, and this is important in design processes. Thanks to this flexibility provided by Unity, the interactions in the game with data such as pictures, animations, and text were easily provided in the game designed in the study. One of the issues to be considered in the game design process with Unity is the design features of the characters and objects to be used. The high resolution of the characters and objects in the game can adversely affect the performance of both the device where the game is developed and the devices on which the game will be played. For this reason, before starting the design, it is necessary to consider the technical features of the devices on which the game is developed and the compatibility with the programs designed. In addition, measures to prevent excessive data load on devices in the process should be planned from the beginning. The code files that enable the characters to move or interact in the game create a significant load during the design and play of the game. For this reason, the recorded code files should be organized systematically. Thus, the code files can be used for different characters and objects in the game without creating a load on the system.

The game design in the study was carried out through the design, development, and evaluation processes of the developmental research method. Education designers face many difficulties when creating a product. One of the problems encountered is the pedagogical design processes of products that require engineering and computer applications (McKenney \& Reeves, 2014). It has

| Kastamonu Education Journal, 2022, Vol. 30, No. 1| 
been observed that developmental research designs that combine the expertise of educators, designers, researchers, and practitioners are a good solution in solving these problems. In the study, the design-based research method was used as an appropriate method for both educational design and for technical development of the game design process.

During the game design and development phase, student levels and player types were taken into consideration while determining the technical processes, preparing the scenario, choosing the game mechanics, and conducting the cyclical processes. Thus, formative evaluations were carried out with the feedback received from experts, and these evaluation and regulation studies have gained continuity with a cyclical process. Therefore, this process has facilitated the achievement of concrete solutions for the targeted goals of the current study. As a matter of fact, Schmitz et al. (2015) carried out gradual regulation studies using the design-based research method in the design of the mobile game-based learning environment. They stated that the design-based research approach is a valid and useful method for educational game design. Although a product is put forward with the evaluation of an expert, it is also necessary to evaluate the game by using it by the target audience. Thus, data regarding the evaluation of the designed game in terms of players should also be obtained. Scenario writing in educational games is also one of the important issues to be emphasized. For this reason, different studies focusing on scenario writing can be done in educational game design processes. In this study, in which scenarios and designs were made for player types, different designs and comparison studies can be made for the use of player types in educational games. Developed game is an example study for educators and designers as it is an educational game specifically designed for player types. There are many studies on educational games in the literature (Busch et al., 2016). These studies aimed to provide education by playing the same game for each player to teach a specific subject. When the results of the study are considered, the current study has gone some way towards enhancing design of an educational game trend by regarding player types in the design process as well. Therefore, the present study is one of the leading studies in the literature on individualized game designs adaptable to player types. In this context, the following recommendations are made for researchers:

- In the study, the design process of the educational game environment according to player types is explained. With experimental studies, the effects of the designed educational game on students' cognitive skills and academic achievement can be examined.

- A model for educational digital game designs can be created by replicating the digital game development processes determined in the study in different game designs.

- Games for different lessons and subjects can be designed according to player types and the effects of these designs on learning can be investigated.

\section{Declaration of Conflicting Interests}

The author(s) declared no potential conflicts of interest with respect to the research, authorship, and/or publication of this article.

\section{Funding}

This study was carried out within the scope of TÜBITAK 1001118 R034 "Developing a Game-Based Adaptive Environment for Programming Instruction for Middle School Students and Investigating the Effect on Students' Computational Thinking Skills".

\section{Statements of publication ethics}

We declare that the study has not unethical issues and that research and publication ethics have been observed.

\section{Researchers' contribution rate}

The study was conducted and reported with equal collaboration of the researchers.

\section{Ethics Committee Approval Information}

Ethics approval was obtained from the Ethics Committee of Karadeniz Technical University with the letter dated 08/09/2017 and numbered 82554930-400-3335.

\section{REFERENCES}

Akgün, E., Nuhoğlu, P., Tüzün, H., Kaya, G., \& Çınar, M. (2011). Bir eğitsel oyun tasarımı modelinin geliştirilmesi. Eğitim Teknolojisi Kuram ve Uygulama, 1(1), 41-61.

Aleem, S., Capretz, L. F., \& Ahmed, F. (2016). Game development software engineering process life cycle: A systematic review. Journal of Software Engineering Research and Development, 4(6), 1-30. doi:10.1186/s40411-016-0032-7

Aleven, V., Myers, E., Easterday, M., \& Ogan, A. (2010, April). Toward a framework for the analysis and design of educational games. In 2010 third IEEE international conference on digital game and intelligent toy enhanced learning (pp. 69-76). IEEE.

Archambault, D., Gaudy, T., Miesenberger, K., Natkin, S., \& Ossmann, R. (2008, June). Towards generalised accessibility of computer games. In International Conference on Technologies for E-Learning and Digital Entertainment (pp. 518-527). Springer, Berlin, Heidelberg. 
Aslan, S., \& Balcl, O. (2015). GAMED: digital educational game development methodology. Simulation, 91(4), 307-319. doi: $10.1177 / 0037549715572673$

Bağcı, H., \& Çoklar A. N. (2014). The evaluation of Celt teacher candidates in terms of computer games, educational use of computer games and game design qualifications. Kuramsal Eğitim Bilim Dergisi, 7(2), 195-211.

Bartle, R. (1996). Hearts, clubs, diamonds, spades: Players who suit MUDs. Journal of MUD research, 1(1), 1-27.

Bilgili, S. (2020). Oyun programlama başarısının çeşitli değişkenler açısından incelenmesi. (Yayımlanmamış Yüksek Lisans Tezi). Ondokuz Mayıs Üniversitesi, Lisansüstü Eğitim Enstitüsü. Samsun.

Bontchev, B., \& Georgieva, O. (2018). Playing style recognition through an adaptive video game. Computers in Human Behavior, 82, $136-147$. doi:10.1016/j.chb.2017.12.040

Bozkurt, A., \& Genç-Kumtepe, E. (2014). Oyunlaştırma, oyun felsefesi ve eğitim: Gamification. Akademik Bilişim, 14, 147-156.

Byun, J., \& Loh, C. S. (2015). Audial engagement: Effects of game sound on learner engagement in digital game-based learning environments. Computers in Human Behavior, 46, 129-138. doi: 10.1016/j.chb.2014.12.052

Busch, M., Mattheiss, E. E., Hochleitner, W., Hochleitner, C., Lankes, M., Fröhlich, P., ... \& Tscheligi, M. (2016). Using player type models for personalized game design-an empirical investigation. Interaction Design and Architecture Journal, 28, 145-163.

Cohen, L., Manion, L., \& Morrison, K. (2017). Research methods in education. UK:Routledge.

Connolly, T. C., Boyle, E. A., Hainey, T., Macarthur, E., \& Boyle, J. M. (2012). A systematic literature review of empirical evidence on computer games and serious games. Computers \& Education, 59(2), 661- 686. doi: 10.1016/j.compedu.2012.03.004

Desurvire, H., Caplan, M., \& Toth, J. A. (2004, April). Using heuristics to evaluate the playability of games. In CHI'04 extended abstracts on Human factors in computing systems (pp. 1509-1512). 24-29 April, Vienna, Austria.

Devary, S. (2008). Educational gaming, interactive edutaintment. Distance Learning, 5, 35-4.

Dimaraki, E. V., Schmoelz, A., \& Koulouris, P. (2013). Scenarios as pedagogical devices: designing activities for game-based learning. ICERI2013 Proceedings, 3203-3209.

Dimitriadou, A., Djafarova, N., Turetken, O., Verkuyl, M., \& Ferworn, A. (2020). Challenges in serious game design and development: Educators' experiences. Simulation\&Gaming, 52(2). 132-152. doi:1046878120944197.

Eagle, M. (2009, April). Level up: a frame work for the design and evaluation of educational games. In Proceedings of the 4th International Conference on Foundations of Digital Games (pp. 339-341). Orlando, Florida.

Ferro, L. S., Walz, S. P., \& Greuter, S. (2013, September). Towards personalised, gamified systems: an investigation into game design, personality and player typologies. In Proceedings of The 9th Australasian Conference on Interactive Entertainment: Matters of Life and Death (p. 7). ACM.

Güler,O., \& Erdem. O. A. (2014). Mesleki eğitimde etkileşimli 3B eğitimin uygulanması ve stereoskopik 3B teknolojisi kullanımı. Bilişim Teknolojileri Dergisi, 7(3), 1-11. doi: 10.12973/bid.2019

Hainey, T., Connolly, T. M., Boyle, E. A., Wilson, A., \& Razak, A. (2016). A systematic literature review of games-based learning empirical evidence in primary education. Computers \& Education, 102, 202-223. doi: 10.1016/j.compedu.2016.09.001

Hong, J. C., Cheng, C. L., Hwang, M. Y., Lee, C. K., \& Chang, H. Y. (2009). Assessing the educational values of digital games. Journal of Computer Assisted Learning, 25, 423-437.

Ike, T. C., \& Hoe, T, W. (2020). Exploring the link between the psychological needs and the elements of game design for educational games. Journal of ICT in Education, 7(2), 65-73.

Indraprastha, A., \& Shinozaki, M. (2009). The investigation on using Unity3D game engine in urban design study. Journal of ICT Research and Applications, 3(1), 1-18.

Jemmali, C., Kleinman, E., Bunian, S., Almeda, M. V., Rowe, E., \& El-Nasr, M. S. (2019). Using game design mechanics as metaphors to enhance learning of introductory programming concepts. In Proceedings of the 14th International Conference on the Foundations of Digital Games - FDG '19 (pp.1-5). New York, New York, USA: ACM Press. doi:10.1145/3337722.3341825

Kallio, K. P., Mäyrä, F., \& Kaipainen, K. (2011). At least nine ways to play: Approaching gamer mentalities. Games and Culture, 6(4), $327-353$.

Kiili, K. (2005). Digital game-based learning: Towards an experiential gaming model. The Internet and Higher Education, 8(1), 13-24. doi: 10.1016/j.iheduc.2004.12.001

Kocadere, S. A., Özhan, Ş. Ç., Bayrak, F., \& Nuhoğlu, P. (2019). Herkül'ün hikâyesi: eğitsel bir oyun geliştirme modeli önerisi. Eğitim Teknolojisi Kuram ve Uygulama, 9(1), 230-250.

Kuzu, A., Çankaya, S., \& Mısırlı, A. (2011). Tasarım tabanlı araştırma ve öğrenme ortamlarının tasarımı ve geliştirilmesinde kullanımı. Anadolu Journal of Educational Sciences International, 1(1), 19-35.

Labschütz, M., Krösl, K., Aquino, M., Grashäftl, F., \& Kohl, S. (2011). Content creation for a 3D game with Maya and Unity 3D. Proceedings of CESCG 2011: The 15th Central European Seminar on Computer Graphics Vienna University, 2- 4 May, 2011, Viničn, Slovakia 1-8.

Lämsä, J., Hämäläinen, R., Aro, M., Koskimaa, R., \& Äyrämö, S. M. (2018). Games for enhancing basic reading and maths skills: A systematic review of educational game design in supporting learning by people with learning disabilities. British Journal of Educational Technology, 49(4), 596-607. doi: :10.1111/bjet.12639

Lester, J. C., Spires, H. A., Nietfeld, J. L., Minogue, J., Mott, B.W., \& Lobene, E. V. (2014). Designing game-based learning environments for elementary science education: A narrative-centered learning perspective. Information Sciences, 264, 4-18. doi: 10.1016/j.ins.2013.09.005 
Malva, L., Hooshyar, D., Yang, Y., \& Pedaste, M. (2020, July). Engaging Estonian primary school children in computational thinking through adaptive educational games: A qualitative study. In 2020 IEEE 20th international conference on advanced learning technologies (ICALT) (pp. 188-190). IEEE.

Manero, B., Torrente, J., Freire, M., \& Fernández-Manjón, B. (2016). An instrument to build a gamer clustering framework according to gaming preferences and habits. Computers in Human Behavior, 62, 353-363.doi: 10.1016/j.chb.2016.03.085

McKenney S., \& Reeves T.C. (2014). Educational Design Research. In Spector J., Merrill M., Elen J., Bishop M. (Eds) Handbook of Research on Educational Communications and Technology. Springer, New York, NY. Doi:10.1007/978-1-4614-3185-5_11

Nacke, L. E., Bateman, C., \& Mandryk, R. L. (2014). BrainHex: A neurobiological gamer typology survey. Entertainment Computing, 5(1), 55-62.

Ninaus, M., Kiili, K., Wood, G., Moeller, K., \& Kober, S. E. (2020). To add or not to add game elements? Exploring the effects of different cognitive task designs using eye tracking. IEEE Transactions on Learning Technologies, 13(4), 847-860.

Prensky, M. (2001). Digital natives, digital immigrants. Digital Natives, Digital Immigrants Part 1, On the Horizon, 9(5), 1-6. doi:10.1108/10748120110424816

Prensky, M. (2004). Digital game-based learning, ACM Computers in Entertainment, 1(1), 1-4.

Qian, M., \& Clark, K. R. (2016). Game-based learning and 21st century skills: A review of recent research. Computers in Human Behavior, 63, 5058. doi: 10.1016/j.chb.2016.05.023

Richey, R. C., \& Klein, J. D. (2005). Developmental research methods: Creating knowledge from instructional design and development practice. Journal of Computing in Higher Education, 16(2), 23-38.

Ronimus, M., Kujala, J., Tolvanen, A., \& Lyytinen, H. (2014). Children's engagement during digital game-based learning of reading: The effects of time, rewards, and challenge. Computers \& Education, 71, 237-246.doi: 10.1016/j.compedu.2013.10.008

Schmitz, B., Klemke, R., Walhout, J., \& Specht, M. (2015). Attuning a mobile simulation game for school children using a design-based research approach. Computers \& Education, 81, 35-48. doi: 10.1016/j.compedu.2014.09.001

Shi, Y. R., \& Shih, J. L. (2015). Game factors and game-based learning design model. International Journal of Computer Games Technology, 2015, 1-11. doi: $10.1155 / 2015 / 549684$

Song, M., \& Zhang, S. (2008). EFM: A Model for Educational Game Design, in Lecture Notes in Computer Science, Z. Pan et al. (Eds.): Edutainment 2008, Springer US. 509-517.

Soyluçiçek, S. (2019). Dijital oyunların sanatsal gücü; konsept tasarımı Süreci. Sanat ve Tasarım Dergisi, 23, 315-327.

Streicher, A., \& Smeddinck, J. D. (2016). Personalized and adaptive serious games. In Entertainment Computing and Serious Games (pp. 332377). Springer, Cham.

Sung, H. Y., \& Hwang, G. J. (2018). Facilitating effective digital game-based learning behaviors and learning performances of students based on a collaborative knowledge construction strategy. Interactive Learning Environments, 26(1), 118-134. doi: 10.1080/10494820.2017.1283334

Squire. K. (2003). Video games in education. International Journal of Intelligent Games \& Simulation 2(1), 49-62.

Sweetser, P., \& Wyeth, P. (2005). GameFlow: a model for evaluating player enjoyment in games. Computers in Entertainment, 3(3), 1-24. doi:10.1145/1077246.1077253.

Taşdemir, Ş., \& Şüyun, S. B. (2016). Bilgisayar oyun tasarımı ve eğitsellik kazandırılmasına yönelik bir yaklaşım. Selçuk-Teknik Dergisi, 15(2), 113124.

Tuunanen, J., \& Hamari, J. (2012). Meta-synthesis of player typologies. Proceedings of Nordic Digra 2012 Conference: Games in Culture and Society, Tampere, Finland.

Van Eck, R. (2015). Digital game-based learning: Still restless, after all these years. Teaching, Leadership \& Professional Practice Faculty Publications, 50(6), 13-28.

Vasalou, A., Khaled, R., Holmes, W., \& Gooch, D. (2017). Digital games-based learning for children with dyslexia: a social constructivist perspective on engagement and learning during group game-play. Computers \& Education, 114, 175-192. doi: 10.1016/j.compedu.2017.06.009

Vasudevamurt, V. B., \& Uskov, A. (2015, May). Serious game engines: Analysis and applications. 2015 IEEE International Conference on Electro/Information Technology (EIT). 440-445.

Xu, Y., Poole, E. S., Miller, A. D., Eiriksdottir, E., Kestranek, D., Catrambone, R., \& Mynatt, E. D. (2012). This is not a one-horse race: Understanding player types in multiplayer pervasive health games for youth. In Proceedings of the ACM 2012 conference on computer supported cooperative work (pp.843-852). Seattle, Washington DC: ACM. doi:10.1145/2145204.2145330

Yıldııım, A., \& Şimşek, H. (2008). Sosyal Bilimlerde Nitel Araştırma Yöntemleri (6. Baskı). Ankara: Seçkin Yayıncılık

Young, M. F., Slota, S., Cutter, A. B., Jalette, G., Mullin, G., Lai, B., et al. (2012). Our princess is in another castle: A review of trends in serious gaming for education. Review of Educational Research, 82(1), 61-89. doi: 10.3102/0034654312436980

Zarraonandia, T., Diaz, P., Aedo, I., \& Ruiz, M. R. (2015). Designing educational games through a conceptual model based on rules and scenarios. Multimedia Tools and Applications, 74(13), 4535-4559. doi:10.1007/s11042-013-1821-1

Zeng, J., Parks, S., \& Shang, J. (2020). To learn scientifically, effectively, and enjoyably: A review of educational games. Human Behavior and Emerging Technologies, 2(2), 186-195. https://doi.org/10.1002/hbe2.188 